December 2006

\title{
The Restless World of Leonardo Alishan (March 1951-January 2005): A Burnt Offering on the Altar of the Armenian Genocide
}

Rubina Peroomian

\section{Recommended Citation}

Peroomian, Rubina (2006) "The Restless World of Leonardo Alishan (March 1951-January 2005): A Burnt Offering on the Altar of the Armenian Genocide," Genocide Studies and Prevention: An International Journal: Vol. 1: Iss. 3: Article 6.

Available at: https://digitalcommons.usf.edu/gsp/vol1/iss3/6

This Articles is brought to you for free and open access by the Open Access Journals at Digital Commons @ University of South Florida. It has been accepted for inclusion in Genocide Studies and Prevention: An International Journal by an authorized editor of Digital Commons @ University of South Florida. For more information, please contact digitalcommons@usf.edu. 


\title{
The Restless World of Leonardo Alishan (March 1951-January 2005): A Burnt Offering on the Altar of the Armenian Genocide
}

\section{Rubina Peroomian}

\begin{abstract}
In his short career as a writer, poet, and literary critic, Leonardo Alishan left a rich literary legacy, a legacy that is not widely known. This article attempts to shed light on an important segment of his literary output: his creations in the genre of genocide literature. Alishan was a third-generation survivor of the Armenian Genocide, the inheritor of his grandmother's devastating memories, living in the grip of the nightmare of the Catastrophe, never able to transcend it. The everpresent pain that dragged his grandmother from one mental hospital to another reverberated in his literary work, painting a microcosm of a victim nation's suffering. As an artist in pursuit of beauty in art, Alishan faced the challenge of overcoming the chaotic world of genocide for the sake of order and perceptual harmony. He was not able to solve, and no one has, the dichotomy between the fragmentation forced upon his art as the characteristic of genocide literature and coherence as a condition of beauty in art.
\end{abstract}

"The Lady-Bug and the Persian Rug," a story depicting a post-mortem dialogue between the author and his dead grandmother, begins with this touching testimony: "Granny had four grandchildren, but she couldn't very well divide herself into four parts. So she chose me. After all, when a house burns down, everyone doesn't necessarily burn with it. I got burned when I was about nine years old."

At first reading, I believed this to be a gloomily pictorial metaphor for Leonardo Alishan's life and his existence, a burnt offering on the altar of the memory of genocide. Now, years later, the story sounds dreadfully sinister. Was this a macabre prediction of a torturous end befitting a torturous life?

Alishan described himself as an Armenian Iranian American, in that order, when prodded to speak about his intellectual identity. He was indeed an Armenian Iranian American writer, poet, and literary critic. He wrote in English and in Persian, but mostly in English, and he dreamed, loved, and yearned in Armenian. He always had difficulty defining his identity: who he was, or, as he wrote, what he was, and why he chose to write in English. In a poem significantly titled "Refuge," he writes,

I need structure

I need form

when the poet is a mad Armenian priest

when the poet is a drunk Iranian cleric

I need clean English

I need Alexander Pope. ${ }^{2}$

Rubina Peroomian, “The Restless World of Leonardo Alishan (March 1951-January 2005): A Burnt Offering on the Altar of the Armenian Genocide." Genocide Studies and Prevention 1, 3 (December 2006): 289-303. (C) 2006 Genocide Studies and Prevention. 
The English language was a refuge to shelter him from the torrential flow of the emotionally laden Armenian and Persian poetic traditions. But it must have been more than that. It was Alexander Pope's fascination with classical tradition and its literary giants that inspired Alishan and guided his own creations: disciplined, concise, with no need for ornaments to hide his want of art, as Alexander Pope would say. "Words are like leaves, and where they most abound/Much fruit of sense beneath is rarely found," Pope advised poets, ${ }^{3}$ and Leonardo Alishan followed that advice.

Alishan was born to Armenian parents in Tehran and immigrated to the United States in 1973 to pursue higher education. With a $\mathrm{PhD}$ from the University of Texas (1981), he taught Persian literature and comparative literature at the University of Utah, Salt Lake City, from 1978 to 1997. He married and had three children. But in the last years of his life he lived alone with his ailing mother, who died a few months before he did. His wife had divorced him and lived in Los Angeles with the children. His family life of nineteen years was shattered, his nest ruined, and he was thrown into a life of ephemeral love affairs and alcohol.

One pillow on my bed

after nineteen years

only one pillow on my bed

filled with nineteen thousand feathers

from the wings of nineteen thousand birds

flown from your hair. ${ }^{4}$

But that was only the circumstantial or physical outcome. This deadly blow in his life had caused a "metaphysical discontinuity," alienating him from the natural world, from everything but the self. In memoriam for Vahé Oshagan ${ }^{5}$ he wrote, "When the self also becomes a complete stranger, the result is madness." ${ }^{6}$ How ironic, as, at times, Leonardo truly was a madman. But were those not the moments when his creative volcano was erupting? Quoting Michel Foucault's observation, it is Leonardo for Vahé again: "Where there is a work of art, there is no madness." 7 And Leonardo's works are truly literary gems.

His poetry, fiction, and essays were published widely in national and international journals. His two collections of poetry, Dancing Barefoot on Broken Glass (1991) and Through a Dewdrop (2000), earned him fame and recognition. He also translated a number of contemporary Persian poems by Nima Yushij, Mehdi Akhavan-Sales, Ahmad Shamlu, and others into English. He was fascinated with Persian poetry, rich with cultural, mythological, and Islamic elements. He was proud of Persian history and heritage, a heritage he grew up with and longed for in his voluntary exile after the Iranian Revolution. He joined poetry-reading sessions with fellow Persian poets, refugees like himself, whose poetry, like his, was full of rage and fury reflecting a deepseated frustration:

For we bite the hand that feeds us!

But know that if we do

it is only because we still remember

after thousands of years, days

when we did not need

to seek safety away from home,

nor to be fed. ${ }^{8}$

Alishan lived with his memories of an innocent childhood in the beautiful Iran of yesteryear. These memories took on an exaggerated aura, becoming increasingly more 
beautiful and enticing: "Exile is the master surgeon of the past. It consistently and continuously works on improving the appearance of the past. Until after a quarter of a century, the past becomes as distant and as beautiful as the Garden of Eden itself." (The piece from which these words are drawn is curiously titled "Salomé's Scars.") ${ }^{9} \mathrm{He}$ never ceased dreaming about Isfahan and the richness of its cultural heritage, a city that embodied all the sweet, innocent memories of a carefree childhood. Isfahan was a haven, Iran a paradise:

Hell was not in Isfahan,

Nor longing. Nor death

$\ldots$

Grape leaves: green hands

made emerald with sunlit rain,

memories crystallized

into clusters of gems ...."10

Instead of a entering into a thorough review of Alishan's literary legacy, this article will only highlight his output in the genre of genocide literature, as, above and beyond his homesickness and yearning for his birthplace, Alishan was a thirdgeneration survivor of the Armenian Genocide, one who lived in the grip of the nightmare of the Catastrophe. He was never able to transcend-or, rather, never tried to transcend-the tragedy that was his grandmother's, the tragedy that became his fate at the age of nine. And he struggled in vain to tell the world the story of that colossal tragedy, his grandmother's story. "The artist is caught between serving his art and convincing people of his own people's collective catastrophe. He plays both the role of the detached artist and the passionate propagandist. Consequently, there is a chaotic confusion of genres and roles, resulting in a frustrated failure," he confessed during an emotional presentation at a 1989 conference at UCLA dedicated to the Armenian Genocide. ${ }^{11}$

This presentation was strangely titled, "An Exercise on a Genre for Genocide and Exorcism." To strive to find a proper genre for artistic expression in genocide literature is quite understandable; but why "Exorcism"? What kind of action did Alishan have in mind, and what was he trying to achieve by that action? He speaks of this again in a story even more strangely titled "The Lady, the Demon, and the Little Exorcist,"12 which returns to his special bond with his grandmother: "Granny was also mother to me. She was my caretaker, my beloved, my teacher, as well as my guardian angel." He recalls the day when his grandmother told him her story for the first time. From then on, he admits, he lost his innocence; he was possessed. "The Genocide had entered my heart and mind. It flowed in my blood and covered my soul. My soul henceforth became as red as Granny's scarf had been when she was fourteen. I now fully felt the presence of that Demon in my life. I still do." An anonymous eleventh-century Persian text on exorcism provided him with the answer to his suffering. "Maybe by telling me she had exorcised the Demon and I, by hearing her, by just being there, had become the new host. Maybe all the poems, stories, essays I have written on this subject are my feeble attempts at exorcising myself. All I know for a fact is that I have failed." Writing did not release him, did not offer catharsis. The Demon continued to live with him, within him: "Writing relieves me momentarily," he writes in that same story, "as drinking did before it became fuel for the Demon. But writing does not scare the Demon away." Critics with a psychological approach to literature would argue the opposite and emphasize the cathartic nature of writing, especially writing about a collective traumatic experience. In fact, writing about such experiences allowed ancient and 
medieval Jewish prophets and scribes and Armenian historiographers to explain historical catastrophes and to reach catharsis for themselves and their readers. For Alishan, such a catharsis was never reached. The Demon of the memories of the genocide never loosened its grip on his soul.

In "The Lady-Bug and the Persian Rug," Alishan speaks of the heavy burden of his "mission" to tell his grandmother's story. She and one of her brothers were the only members of their family who survived, having left sixty-two relatives dead on the road of deportation in the Syrian Desert. Alishan grew up with the horrible stories of how Granny's family members perished, but it was the story of the red scarf that made the deepest impact on his psyche. His grandmother, Gayané, was only fourteen at the time of the experience, and after that she stopped living. The torture, the devastating memories of that dreadful trek, haunted her all her life. She "stopped being a girl and became the statue of Guilt." She cried when she was alone, or when she thought she was alone, as Leonardo remembers, and was periodically taken to a mental clinic for rehabilitation. Leonardo was only nine years old when she chose to tell him why she was so miserable and why she cried all the time:

One day the Turkish captain rode past her on a dappled horse. She was wearing a red scarf which was her most cherished possession. The captain said, 'Tonight I will come for you.' An old woman told Granny to throw her scarf away. She did. That evening she saw the captain ride away with a girl who had picked up Granny's red scarf and had worn it. The captain returned without the girl. Granny cried tears of relief on that night for which she paid with tears of remorse for the rest of her life. ${ }^{13}$

The theme of shame and remorse for having survived at the price of others' deaths is a rare occurrence in Armenian Genocide literature, but, curiously, one encounters these ever-torturing feelings in oral interviews of survivors. Perhaps these are raw, untreated emotions that subside in literary responses to genocide.

Alishan's strongest literary creations are about his "Granny" and "bearing witness to her agony." He shares her agony; he is a part of it.

I try to be a spectator of that tragedy which culminated in a London hospital room in 1978 where Granny saw Turkish horsemen around her bed before she died. But, alas, I am not the spectator. I am a character caught in that play which never, never, never reaches its equilibrium. ${ }^{14}$

"Gayané, the living martyr," as he pictures his grandmother, governs his life and his emotions. She is a constant presence in his dreams, in his waking thoughts. It is through his grandmother that, like most third-generation writers, Alishan sees the Armenian suffering, the Genocide. Similarly, Carol Edgarian, Peter Balakian, and Micheline Aharonian Marcom, among others, have written powerful novels based on their grandmothers' stories. These young writers chose to learn about the dreadful past of their grandparents, a past often covered up and forgotten by their parents. With the distance of time and space from the event on their side, and with acquired skill in the poetics of genocide, they eternalized a fragment of the story of the Armenian Genocide.

"Seventy-five percent of my poems are either about Armenia or Granny. And Granny is the Genocide. She is also Armenia," Alishan notes. ${ }^{15}$ His love for Armenia turned into a tangible inspiration when, together with a group of scholars, he traveled to Yerevan in the fall of 1991 to take part in a symposium organized jointly by the UCLA Narekatsi Chair of Armenian Studies and the Yerevan State University Department of Literature, where he presented a paper titled "The Return of the Great Goddess in the Hayrens of Nahapet Kuchak." That experience was both a torturous 
and a happy one for him. He was anxious about delivering his paper in Armenian; he was intimidated by the presence of Armenologists who would look down on him for his lack of fluency and his faltering delivery. He correctly anticipated that there would be many know-it-alls in the audience who would not pay attention to the content, the novelty of approach, and the deep insight of his research, who would smile in contempt at his struggle to produce Armenian words. But he had to make that journey; he "had to return to [his] mother." 16 And he returned. He deeply impressed those Armenian scholars who could see beyond his student-like shyness and simple delivery of the Armenian language.

Alishan fell in love with every stone in Armenia. He was astonished to see an eighteen-year-old Armenian prostitute waiting for clients in a dark and almost empty bar in Yerevan. When she told her sad story, how she had to sell her body for seventy rubles (about two US dollars, at that time) to earn a living, he wept and gave her all the money he had in his pocket.

Leonardo's choice to present a paper on Nahapet Kuchak's world of poetry must have been a conscious decision, as he ended his presentation by drawing a parallel between Kuchak's return to the Mother Goddess of the world of heathen Armenia and his own return to his sacred mother, Armenia. Both their journeys were painful, and the centuries-old longings had remained unquenched. ${ }^{17}$ Armenia had revealed herself to him in all her beauty and ugliness, as a reality that had no congruity with the land of dreams he had sung in his many poems dedicated to Armenia. Armenia had been to him "a strange child of love and pain," his Granny incarnate, everything she represented: "the tears of Granny," instilling melancholy in his young and innocent soul, "the hands of Granny," inspiring security and serenity in a frail and timid boy. ${ }^{18}$ And now he faced a reality full of life, not of "Broken bridges. Burnt books. / Shells filled with sharp shrieks,/Madmen wandering in tattered shirts/dragging shackled dreams along," as he envisioned her in "My Armenian History Book." Armenia had now become, for Alishan, a "private double-edged sword: a painful historical past and a loving utopian future."19 She had lost her symbolism to a reality that was appealing and alien at the same time. And Leonardo did not belong to that life: "I now knew, I knew, I knew that I did not belong." ${ }^{20}$ Alishan was a Diasporan Armenian, unfamiliar with Soviet Armenian society and the influence of seventy years of Soviet rule on the Armenian lifestyle, outlook, and identity. His experience, however, was not unprecedented. Hakob Karapents, another Diasporan Armenian writer, remembers his first encounter with fellow Armenians in their stormy circle-dance in the story "Haykakan shourjpar" ("Armenian Circle-Dance"). He tries to participate, but the music and the movements come from the depths of the Armenian soil, and he is only a visitor who has lost the rhythm in the streets of America. He is a stranger with awkward movements. He does not belong there. ${ }^{21}$

Alishan's diffuse and dispirited thoughts reverberate in "From Dream to Reality: Don Quixote with a Dead Horse and Windmills with No Wind," his travelogue of his first and last encounter with Armenia. "Who was I now?" he asks himself again in this artistic self-analysis and assessment. And the answer is, "A man with an American passport who taught Persian literature and Iranian culture and civilization in an American university, and said I love you in Armenian to his children and dreamt in Armenian." He reiterates his poem about why he has chosen to write in English. In an interview with Ara Oshagan in 1992, asked where he would place himself among other Armenian poets writing in English, he responded, "My sensibility in poetry is probably 
Persian, content often Armenian, expression "American.... I know I dream" in Armenian, I teach Persian, write English. What am I, I don't know."22

What he knew for certain was that he "had wrongly sought a sense of security and serenity in an external phenomenon such as Armenia, instead of searching for it within the dark waters of [his] own soul." He knew why he kept yearning for a sense of belonging, for security and serenity: "I have been homesick in all my homes," he writes. "I must have been the sick limb of an old god, amputated and dumped into this world." 23 The reality he discovered in Armenia and his constant search for deliverance did not alleviate the ever-present pain of a traumatic past transmitted to him by his grandmother-the pain of his butchered family, his butchered nation, but, above all, the pain of having a mission to tell the world about that colossal injustice, the genocide, and failing in his mission.

Gayané remained the embodiment of the Armenian Genocide and her story the microcosm of a victim nation's suffering. She became the omnipotent face of the nation's suffering, appearing in Leonardo's poetry as a mad woman who sees Turkish horsemen around her deathbed in a mental hospital in London. ${ }^{24}$ She is a ladybug living on the Persian rug in his bedroom, talking to him, nagging him about why he is so inept in telling the world her story and about the tragedy that befell her nation. ${ }^{25}$ She is a hungry tigress ready to consume the Mahasattva. ${ }^{26}$ She becomes God's daughter Antigone (Antigone is in fact the daughter of King Oedipus in Greek mythology), as God blinds himself and becomes a wanderer after helplessly watching the Armenian deportations. ${ }^{27}$ She is the statue of Mary ever burning, ever weeping tears like drops of burning wax, charring his dreams and his consciousness:

In the center of my dream

there is a church of stone in Van

sealed from outside

exhaling screams and smoke from the inside,

its congregation of Armenian folk

replacing the candles with their flesh.

There is a church in my dream

made with the bones of dead gods,

babies and parrots' prayers;

always, all night, in flames

but never burning to the ground.

And in the church burns a statue of Mary

With my Granny's face, wax dripping down her eyes

drop by drop, on the skin of my dreams... ${ }^{28}$

In order to fully grasp the meaning of Alishan's writings, it is important to know the Bible, in addition to Greek, Persian, and Armenian mythology and classical literature, as well as modern international literature and literary criticism. Alishan made frequent reference to all these sources in parallel or contrasting situations, or simply to draw metaphors. He was a master of all these traditions, yet did not adopt any of them as his own. He searched constantly for the most powerful poetic form. He was not only a master of artistic expression but also strove to reach that ultimate depth of intended effect with the smallest number of words, much like a master painter who can create the mood and effect of a meticulously painted landscape with just a few strokes of his brush. He once wrote about poetry, "A good poetry is a Japanese painting: Ladies Taking a Stroll on a Summer Day. We see their kimonos in motion, 
hence the stroll; their fans, also in motion, hence summer." ${ }^{29}$ He was a master of strong effects in brevity. This is why he was drawn to tanka, haiku, and senryu. ${ }^{30}$ Through a Dewdrop, published in 2000, is a two-part collection of haiku, senryu, and tanka. ${ }^{31}$

The first part of Through a Dewdrop, titled "THESE DYING DAUGHTERs," embodies Alishan's somber thoughts on a variety of themes. These are three-line poems, mostly haiku and some senryu. Predominant in these poems is the shadow of death casting its pall over the most enchanting images of nature, death as a threat to his rarely achieved peace of mind and serenity, as an invitation to put an end to the unending sufferings, as a temptation to suicide:

death has taken

the day off

to baby-sit $\mathrm{me}^{32}$

A senryu with a touch of satire for his torturous life:

it's spring, not a time to die

I tell the snowman

and hope he will confirm ${ }^{33}$

Or,

a blade of grass

grown through a rock

thwarts thoughts of suicide ${ }^{34}$

The last haiku at the end of the first part is a return to the mysterious title, "THESE DYING DAUGHTERS." It brings closure to the obscure psychic complex of emotions of loneliness, of his hopeless love for his one and only wife, of his refuge in the world of alcohol:

incurable disease

these dying daughters

my hands ${ }^{35}$

His hands are a part of the whole, representing the whole, the Alishan person, the body, the soul, the psyche, tangled in insurmountable hardship, with death as the only salvation.

Then comes a series of five-liners in tanka form in the second part, titled "MY INERT HANDS"; the hand symbol persists. The atmosphere remains the same; the themes are more variegated, more enigmatic, with some insinuating lewd (lascivious) imagery, left to the reader's interpretation. Some of the tankas are very simple depictions contrasting his complex obsession with life and death:

green green, yellow green

yellow yellow, yellow red

red red

dead

the falling maple leaf ${ }^{36}$

Others paint the cruelty of this unjust world:

children

silently starving to death

the light in their eyes

as pale as the childhood memory

of a just God $^{37}$ 
The tanka entitled "Utilitarianism" reflects the cruelness of his own fate, the sad story of his own family:

mom's gone to church

the more loved ones she loses

the more she loves God

I feel God loves her love so much

He's going to take me too ${ }^{38}$

And again, the last tanka returns to the title and depicts once again the irony of Alishan's meaningless life:

at night

I change the flint

add lighter fluid to my zippo

and tell my inert hands

at least we have done something today ${ }^{39}$

In Through a Dewdrop, thoughts and images converge to form a beautiful tapestry, the extraordinary, the unconventional, the crazy life of a gifted poet. Even in this unfamiliar new form, as his reviewers Jane and Werner Reichhold attest, "he remains true to his heritage and background by bending the spirit of the form to fit him instead of folding himself and his impressions into Japanese poetry." 40

Why this fascination with these Japanese forms of poetry? Perhaps it was a drive to try his hand at a borrowed genre in American poetry in which very few had succeeded, to show his talent and flexibility to adapt to any mold to pour out his thoughts, to create. It is more plausible, however, to think that what attracted Alishan to these genres was the challenge of poetic expression par excellence. I compare this motivation to the Armenian literary trend of composing quatrains in the late nineteenth century. It is not easy to mold one's thoughts, didactic, philosophic, or purely emotional, in four lines; it took a Hovannes Tumanian to achieve it. Haiku, tanka, senryu, or quatrain, Alishan's poetry is always concise, without a superfluous word, always focused, always to the point. Remove a word, an adjective, a metaphor, and the structure will collapse. His fascination, however, goes beyond the form. On a photocopied page of a tanka poem titled "Kingfisher," composed of five separate five-liners, published in the Tanka Journal of Tokyo in $2000,{ }^{41}$ he jotted down in Farsi, "Each one (each five lines) is a separate poem; yet, in a whole, they carry common denominators. Important is the theme of literature and visual arts of the Far East."

Alishan remained obsessed with the untold story of the Armenian Genocide. He remained obsessed with the love, the fate, the horrible stories of human suffering. He was a humanitarian, a sensitive soul whose heart embraced all human sufferings, all children living in abject misery and threatened with death by starvation in the far corners of the world:

If I had hands

as big as my heart

I would take all small

and big flags of all the big

and small nations and I would

sew them with my big hands

into the biggest blanket and tent

the world has ever seen 
for all her naked children-

I wish I had hands

As big as my mouth! ${ }^{42}$

He was outraged by the ongoing NATO-led military campaign in Afghanistan, where innocent men, women, and children were falling victim not only to the hypocrisy of American humanitarianism but, even more so, the hypocrisy of God, the omnipresent but helpless God watching the carnage with shredded heart:

They have buried ten million mines

in Afghanistan, one land mine

for every two or three Afghans,

regardless of age or ethnic background.

They have planted death in the womb

of the mother. Prosthetic limbs are airdropped

with food. They have planted a mine

under God's pillow and his dreams of doves.

Every night a new dark dream spreads

its wings in my sleep. This morning I woke

with a throbbing headache. I woke tired.

I had defused or detonated mines all night.

A dream so real, I checked my limbs.

They were still mine. A dream so dark

I checked my heart. God was still there.

But also still mine and also still there

was the problem of ten million mines,

ten million limbs, ten million lives, ten million

dreams, blown apart in the heart of a God

who plows with the farmers and lives in my heart. ${ }^{43}$

Alishan's prose covers a wide range of topics. His profound knowledge in Eastern philosophy, encapsulated in traditional tales and proverbs, provided him with raw material for his didactic and philosophical parallels. It gave him the opportunity to delve into the deepest layers of human nature, its hidden desires and animal instincts overpowering will and controlled behavior. But again, when it came to telling the story of the Armenian Genocide, the challenge remained insurmountable. He kept on striving to find the proper means of expression for telling that story to the world, for best picturing the inexplicable truth of genocide. "There is no proper genre for giving an artistic expression to the genocide," he complained. "The novel comes closest but that too does not suffice. The particular bears witness to the general. But though this witness tells the truth and nothing but the truth, it fails to tell the whole truth." ${ }^{44} \mathrm{He}$ never tried his hand at that particular genre. Poetry was his forte; even his prose was a musical unrhymed poetry.

The Red Scarf (2000), the only play he wrote, flows like poetry and, not surprisingly, is about his grandmother's ordeal in 1915, at the age of fourteen, a young girl wearing an Erzurum costume and a red scarf over her long hair. In the play, she appears as an apparition that only Aram, the main character, can see. The Red Scarf is staged in a contemporary setting; the events occur in 1978 (the year Alishan's grandmother died in a London hospital). The play is the fictionalized reflection of Alishan's own life as a university professor, a family man with a turbulent married life, whose grandmother lives with his family but is now sick in hospital. Alishan adopts the form of ancient Greek tragedy, yet another indication of his admiration of classical 
tradition: a chorus onstage intervenes to facilitate the flow of the present-day story. In this case the chorus is composed of three women, perhaps representing the three women in his life: his teenage daughter (the Girl), his beautiful wife (the Younger Woman), and his mother (the Older Woman). But then, perhaps, they also represent the three stages of Gayané's life. The chorus begins,

Older Woman: ... Could we be the generations, not just ours, but all the nations.

Could we speak for all the dead

Younger Woman and Girl: $\quad .$. those who lived and begged for bread; those with bedrooms filled with ghosts, and molded skulls on new bed posts?

Older Woman, Younger Woman and Girl: Let us stay and let us see If any of them can be free. ${ }^{45}$

The stage is set for the play to unfold. Can Alishan himself be set free at the end, liberated from his nightmares and apparitions? Is there a way to set free generations of survivors of collective trauma anywhere in the world?

Alishan gives fictitious names to the main character (Aram) and his wife and daughter, but he does not attempt to change his grandmother's name, Gayané; the imprint of that name was too deep to be easily replaced. Names and persons, it seems, can be changeable, interchangeable, and dispensable for Alishan-but not Granny, not her, not her name. She is a symbol; she is his creator, a goddess, the goddess of pain and suffering whom he worships as pagan priests worship their gods.

Aram's grandmother is a seventy-eight-year-old woman (the age of Granny when she died) living the last days of her life in a mental hospital, removed from the reality around her, aware only of her flashbacks of 1915. No one understands why Aram is so much engulfed in these flashbacks himself, why he cannot forget the past and go on living his life. To a question from Granny's Jewish nurse, Aram replies, "Well, Rachel, maybe it's because while history has accepted the reality of your catastrophe and you've been able to go on and write successful books and make good movies about your tragedy, while for you, that holocaust is raw material for making movies or writing books, for us it's still undigested history."46 This explanation encapsulates Alishan's own viewpoint as he compares the Jewish and Armenian experiences and their effect on survivor generations. It draws on the author's belief that the Jews enjoy reconciliation, and can create art from the ashes of the Holocaust, because the Holocaust is a recognized truth, while Armenians still have to struggle for the recognition of the Armenian Genocide.

Combining all possible genres of artistic expression, and with the help of the Bible and appropriate psalms, choral interventions, flashbacks, and dialogue, Alishan presents a detailed picture of his own life in relation to his family's past history-the genocide at its core-his mother, his wife, and, of course, his grandmother. He does not shrink from quoting his own poetry or the stories of Gayanés red scarf that he has heard "a thousand times," the tragic event on which he has "published a poem, a story, an essay..." But here the story, especially Gayané's last flashback in her dying moments, is staged with nightmarish dramatization, as the climax of the play.

The scene opens in a bar as Gayané's nurse walks in to give Aram the news of his grandmother's death. The chorus sings the finale. The Older Woman tells of the death of the body that went on living and growing old after the little girl died at the age of fourteen; the body is now joining with her real self. The Younger Woman mourns her own happiness and beauty, which was wasted because of 
the extraordinary love between a man and his grandmother, both victims of the undying pangs of morbid memories. "Is she gone? Is it done?" she asks the Older Woman. She doubts whether Granny's death-that is, her physical absence-can mitigate emotions and painful memories to bring normality into an insane relationship. The Girl wants to live. She wants to forget everything and live her life as a normal human being, without the burden of the past weighing heavily on her soul.

The play concludes; yet a question still haunts the minds of the spectators. In the beginning, the chorus sang, "Let us stay and let us see/ if any of them can be free." Who is truly set free, now that Gayané, "the living martyr," is no more? Now that her story has spilled out, will there be deliverance? Aram leaves the bar with a brown bag containing a bottle of liquor under his arm. He is taking home a red shawl, a gift from the barman to his daughter. The story of the red scarf/shawl continues. The Girl leaves the stage shouting, "This isn't fair!" 47 The prospect of a normal life in the future for her is dim. Aram and his wife face each other without seeing each other. Ominous shadows cast their spell on their future family life. No one is free! No one is delivered from the burden of the past!

To my knowledge, Alishan never published this play, despite many encouragements. The piece promised to deliver him from his burden of "guilt," but it did not. He continued to think that he had betrayed his grandmother; he had broken his promise to her; he had deprived himself of her love because he had failed to fulfill the mission she entrusted him with in his dreams, in his waking thoughts, in his soliloquy with her ghost. The imaginary words, the celestial mission, Granny's conditional love for him, reverberates in his creations:

“... My darling, if you want me to love you

forever and ever, you must be shed

as the tears of the tribe; you must

become, my son, the voice of the dead." 48

There was no deliverance. The burden was his to carry for life:

... I search hopelessly for some shade

in this ashen April desert

to put my Granny down and rest.

She is heavy and I am old now

and feel the weariness.

And it does not seem to matter that I first began

to carry Granny on my back

when she was thin and fourteen

and I was barely nine years old. ${ }^{49}$

Alishan's agony and his obsession with the untold story of the Armenian Genocide, indeed, intensified every year as the month of April neared-more so in his last years, when he lived in his mother's duplex and slept in the basement, when he felt deeply the effects of "metaphysical discontinuity," when he felt he had failed his family, his children:

\section{April,}

why is there so much life with you

and with me the living dead?

This is the first stanza of the poem "April, Since 1915," the second of the sequence of four unpublished poems titled "Victims: The Return of the Cruelest Month." In this 
poem Alishan remembers how he wept when he heard that a fanatic had splashed acid on the face of a pretty girl because she had not covered her face with the Islamic veil. Drawing a powerful analogy, he asks,

Sweet April, if I pitied her

why do I question you

when I should be weeping for you

and questioning the Turk

for what he's done to your face?

For Alishan, April was indeed a month to go absolutely crazy, out of control, drunk and out of touch, with constant phone calls to his friends, conversations that he did not remember the next day, and desperate attempts at suicide. But the result, almost always, was a masterpiece, a poem or a series of poems as sacrificial lambs to the memory of his dead, all one-and-a-half million of them, who seemed to rise from their nonexistent graves and fill his room and his soul with their shadows:

The Armenians driven from their homes to the desert and repatriated to the world of spirits eighty-seven years ago, do not wait for me only in April and only on the 24th. That is merely the day they congregate into an army of ghosts and hound my hours.... 50

He begs to be set free:

I've heard the stories these ghosts tell:

I've heard those other ghosts as well.

Dear God please do your best to put all my ghosts to rest. ${ }^{51}$

And in every piece he writes, Granny is a presence:

It's April

She is the hungry tigress again and I, as some Bodhisattva, Mahasattva, serve myself to her again. ${ }^{52}$

Sometimes Alishan annotated the poems he sent his friends. I received "April, Since 1915 " on 15 May 1999 with a few lines attached:

While you were away I was nursing my pregnancy which resulted in the birth of this poem. Every time I think I'm done, I am not done-I have more. It is the longest poem I've ever written. I happen to think it is also one of the best.

In this long twelve-part poem, Alishan appears not only as a selfless being who sacrifices himself for his beloved Granny but also as a sculptor, a blacksmith, a diamond cutter, and so on as he tries to forge the history of his tribe. But this history speaks only about injustice, about torture, about God's inability to intervene. And then there is Granny again, this time as the queen of King Oedipus. This reference to the legend of Oedipus is curious and inexplicable:

Granny, queen of my heart, heart of every April, may my eyes be pierced with your pin if I ever turn my back on you, my love. ${ }^{53}$ 
He concludes “April 24, 1915" with a subtle hint of Buddhist morality:

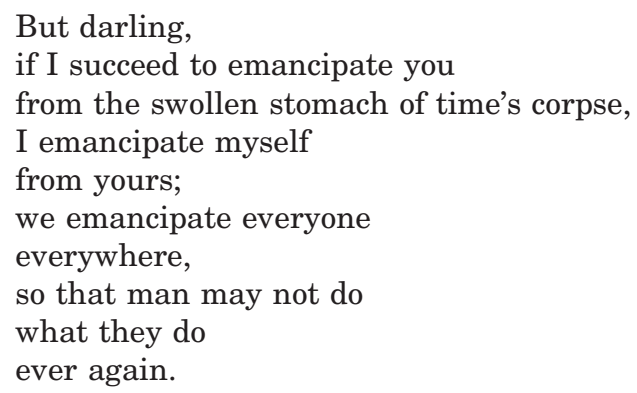

Leonardo Alishan was a passionate person. He related and reacted to everything around him passionately. He fell passionately in love with his kindergarten teacher, resulting in an embarrassing scene that he could not forget for the rest of his life ${ }^{54}$ His love for Granny crushed his stability and equilibrium, throwing him onto a roller coaster of emotions from which he was never able to disembark. He fell in love with anything beautiful-a work of art, a piece of music, a beautiful woman. His longing for beauty, his quest for perceptual harmony and order, stood in stark contrast with the chaotic world that engulfed him, the world of genocide, where order and harmony had no meaning. As an artist in pursuit of beauty in art, Alishan faced that impossibility and declared his failure to overcome the challenge. He was not able to solve, and no one has, the dichotomy between the fragmentation forced upon his art as the characteristic of genocide literature and coherence as a condition of beauty in art.

In his painful trek, there was a bridge he often crossed between his passions and obsessions. He remained haunted by the ghosts of his dead, the victims of the Armenian Genocide, “The unacknowledged ghosts of 1915"-ghosts who never left him, not in April nor in the rest of the year:

... my ghosts

hide in places where one

would expect them the least;

like in the "I love you" a failed father

finds in a card he opens

when he has been drinking all day

to forget it's Father's Day. ${ }^{55}$

Leonardo Alishan died on 9 January 2005, when a fire tore through his Salt Lake City home. The house burned down, and he, the lone habitant, burned up with it. His macabre prediction had come true: he had met a torturous end befitting his torturous life, the life and death of a burnt offering on the altar of the memory of genocide.

\section{Notes}

1. Leonardo Alishan, "The Lady-Bug and the Persian Rug," Ararat 35, 140 (Autumn 1994): 32 .

2. Leonardo Alishan, "Refuge," in Dancing Barefoot on Broken Glass (New York: Ashod Press, 1991), 51.

3. Alexander Pope, "An Essay on Criticism," in Critical Theory since Plato, ed. Hazard Ames, 281 (New York: Harcourt Brace Jovanovich, 1971).

4. Leonardo Alishan, "The Nest," Visions (1999).

5. Vahé Oshagan was a revered Armenian poet, writer, and critic with whom Alishan had developed an intellectual bond.

6. Leonardo Alishan, "Vahe Oshagan (1921-2000)," Ararat 41, 160 (Autumn 2000): 64. 
7. Ibid.

8. Leonardo Alishan, "To an American Friend Who Loves Persian Poetry," in Oberon, poetry 2 (2003): 21.

9. The copy of this piece in my possession is a photocopy of page 31 of an unnamed magazine or anthology, sent to me by Alishan.

10. Leonardo Alishan, "Remembrances," Lullwater Review 13, 1 (Winter 2002): 73. This poem won him the Lullwater First Prize.

11. Leonardo Alishan, "An Exercise on a Genre for Genocide and Exorcism," in The Armenian Genocide, History, Politics, Ethics, ed. Richard G. Hovannisian, 340-54 (New York: St. Martin's Press, 1992), 352-53.

12. Leonardo Alishan, "The Lady, the Demon, and the Little Exorcist," unpublished manuscript, circa 2003. Subsequent quotations in this paragraph are from the same source.

13. Alishan, "Lady-Bug," 32.

14. Alishan, "Exercise on a Genre," 352.

15. Ara Oshagan, "Once in a While It's OK to Walk Naked in the Crowd: An Interview with Leonardo Alishan," Asbarez English Weekly, 14 March 1992, 7.

16. Leonardo Alishan, "The Return of the Great Goddess in the Hayrens of Nahapet Kuchak" (in Armenian), paper presented at UCLA Narekatsi Chair of Armenian Studies/Yerevan State University Department of Literature symposium, Yerevan, fall 1991.

17. The feminine principle and the concept of the Goddess was rejected in early Christianity and replaced by the concept of the Church (Mother Church) to function as the giver of life. This anti-feminine attitude prevailed in Armenian lyric poetry-all, incidentally, composed by clerical poets-until the hayrens of Nahapet Kuchak, the medieval Armenian secular poet. In this genre of poetry, Kuchak attributes to women all three functions of the pagan Goddess: giver of life, transformation, and giver of death. After millennia of rejection, the pagan Goddess returned to Armenian poetry, and Kuchak to the pagan Goddess, to the source of life.

18. Leonardo Alishan, "From Dream to Reality: Don Quixote with a Dead Horse and Windmills with No Wind," Ararat 32, 132 (Autumn 1992): 23-27, 23.

19. Ibid., 26.

20. Ibid., 23-24.

21. Hakob Karapents, "Haykakan shourjpar," in Ankatar [Incomplete], by Hakob Karapents, 12 (New York: Voskedar Press, 1987).

22. Oshagan, "Once in a While," 7.

23. Leonardo Alishan, "Deathtime 1," in Dancing Barefoot on Broken Glass (New York: Ashod Press, 1991), 70.

24. Alishan, "An Exercise on a Genre."

25. Alishan, "Lady-Bug."

26. Leonardo Alishan, "April 24, 1915," Armenian Weekly, 27 May 2000.

27. Ibid.

28. “ЕССЕ номо," unpublished, 2000.

29. Leonardo Alishan, "Poetry," ByLine, June 2002, 18.

30. Tanka is one of the oldest and most important forms of Japanese verse. English-language tanka is somewhat different and may contain more images than in the Japanese tradition, with its set structure of thirty-one syllables. It is composed in five lines. In the best tanka, the five lines often flow seamlessly into one thought. Tanka is concise and evocative; it usually celebrates a moment, an event, and a memory. Haiku relates mostly to nature and natural phenomena. Senryu is mostly about human behavior and has a subtle satirical tone. Michael Dylan Welch calls the senryu "poems of human selfawareness." Ray Rasmussen, "Senriu: Definitions and Pronunciation," Senriu entry page, http://raysweb.net/senriu/definitions.html (accessed 25 July 2005). Both haiku and senryu are very short pieces, "a comfortable breath-length," unrhymed three-liners, and it is often very hard to differentiate between the two forms. Many English and American poets, beginning with James Joyce and Ezra Pound in the period between 1910 and 1917, were 
inspired by the simplicity and profundity of haiku and senryu, using these forms to express their impressions of natural phenomena and human behavior as well as their emotions. The movement, however took root only after the $1970 \mathrm{~s}$, however, with the emergence of periodicals devoted to these forms. Haiku and senryu have since flourished in North American literature.

31. Leonardo Alishan, Through a Dewdrop (Los Angeles: Open Letter, 2000). Some of the poems in this collection first appeared in prestigious literary journals such as American Tanka, black bough, Grandmother Earth, Japanophile, Lynx, Modern Haiku, Palomar Showcase, Penumbra, Point Judith Light, Raw Nerves, Sisters Today, Spin, Winter SPIN, Tanka Journal, and Tundra.

32. Ibid., 52.

33. Ibid., 10.

34. Ibid., 11.

35. Ibid., 56.

36. Ibid., 64 .

37. Ibid., 70 .

38. Ibid., 81.

39. Ibid., 101.

40. Jane Reichhold and Warner Reichhold, review of Through a Dewdrop: A Collection of Haiku, Senryu and Tanka, by Leonardo Alishan, LYNX: A Journal for Linking Poets 16, 1 (February 2001), http://www.ahapoetry.com/ahalynx/161bkrv.htm (accessed 16 October 2006).

41. Leonardo Alishan, "Kingfisher," Tanka Journal 15 (2000): 6.

42. "Utilitarianism," Sufi 58 (Summer 2003): 43.

43. Leonardo Alishan, "Tired Thoughts," Burning Bush Publications, http://www.bbbooks.com/ winner2003.html (accessed 17 October 2006). "Tired Thoughts" won the People Before Profits Poetry Prize of 2003. Alishan's other awards include the Academy of American Poets Award (1977), New England Poetry Club's Daniel Varujan Award (1981), and the Lullwater Review Poetry Prize (2002).

44. Alishan, "An Exercise on a Genre," 352.

45. Leonardo Alishan, The Red Scarf (unpublished playscript, 2000), Act I.

46. Ibid., Act II.

47. Ibid., Act III.

48. Leonardo Alishan, "Conditioning" (unpublished, 2002).

49. Leonardo Alishan, "Growing with My Heritage (for Two Victims of the Armenian Genocide)," fourth in the sequence of four unpublished poems titled "Victims: The Return of the Cruelest Month," written in April and May 2002.

50. Leonardo Alishan, "The Victim's Ambush," third in the sequence "Victims: The Return of the Cruelest Month," unpublished.

51. Alishan, "April 24, 1915."

52. Ibid. In Tibetan Buddhism, a Bodhisattva is anyone who is motivated by compassion and seeks enlightenment not only for him- or herself but also for everyone else. Mahasattva was one of the earlier reincarnations of Buddha, who threw himself in front of a hungry tigress and her hungry cubs to become their food.

53. Ibid.

54. He wrote about this event in "The Smile (A Sunflower for Ms. Armik Gogozian)" (unpublished manuscript, November 2001), describing how his parents were called to meet the kindergarten director and the teacher to explain their five-year-old son's strange confession of love.

55. Alishan, "The Victim's Ambush." 


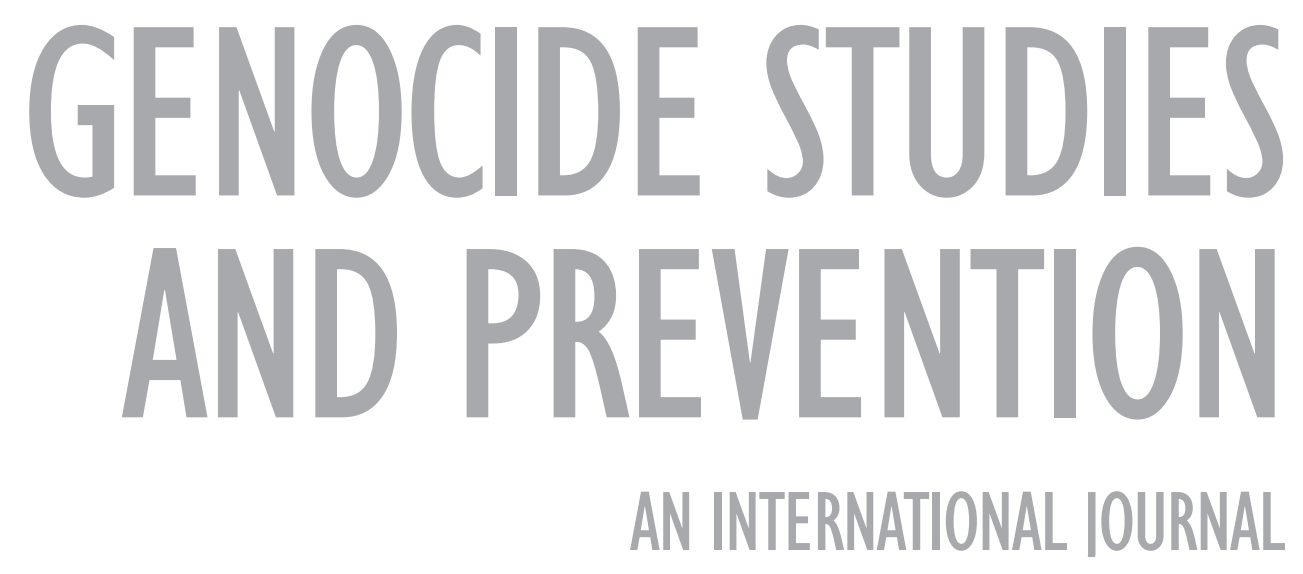

